\title{
An Analysis of the Significance of Gestalt Theory in English Listening Tests and English Vocabulary Teaching in Universities and Colleges
}

\author{
Li Yun* \\ Xi'an University School of Foreign Studies \\ Xi'an, China \\ 1094638852@qq.com \\ * Corresponding Author
}

\begin{abstract}
Gestalt is an important term of psychological field, and it is also one important school of the studies of psychology as well. Relevant theories of gestalt also play an important role in English teaching in universities and colleges. There is a close relationship between English listening comprehension tests and cognitive linguistic theory, so that gestalt theory and relevant principles are also full applied in English listening tests in universities and colleges. Besides, the connotation of integrity of gestalt theory has been also applied in the process of English vocabulary in universities and colleges. The purpose of this paper is to makes an analysis of the application of gestalt theory in English listening tests and English vocabulary teaching in universities and colleges in order to promote development of English teaching in universities and colleges in China. This paper is mainly a qualitative and documentary research. In conclusion, this paper starts from the angle of Gestalt theory in explore laws in English listening tests and teaching strategies of English vocabularies in universities and colleges so that students can actually participate in the process of knowledge construction of English learning in universities and colleges.
\end{abstract}

Keywords-Gestalt Theory; English Listening Tests; English Vocabulary Teaching; Universities and Colleges

\section{INTRODUCTION}

Gestalt is an important term of psychological field, and it is also one important school of the studies of psychology as well. As a psychological theory, gestalt theory has close relationship with many linguistic fields, especially cognitive linguistics. Many teachers just regarded English vocabularies as the key point of English learning and teaching under the influence of traditional English teaching methods and the existing examination system for many years. In the view of English teachers, the enlargement of students' English vocabulary can improve their language abilities. Therefore, they spent much time to explain the usage of English vocabularies in isolation, but they put the integrity English teaching method in the second place. In this way, the integrity of English classroom teaching in universities and colleges was broken, and this is not favorable to grasp contents and meanings of English texts on the whole. Besides, English listening teaching and the role of listening tests are often ignored in universities and colleges. [9] A large amount of English vocabulary explanations will make students become bored and there will be also not a good effect in English learning and teaching in universities and colleges. The purpose of English education in universities and colleges is to improve students' comprehensive ability as well as communicative ability of using English, so proper teaching methods can not only improve English classroom teaching effect, but also it can guide students to form a habit of taking rational learning strategies in English learning in universities and colleges. As a result, this paper mainly makes an analysis of Gestalt principles of cognitive linguistics in English listening tests and English vocabulary teaching so as to find some laws and propose some teaching strategies for English teaching in universities and colleges. ${ }^{[2]}$

\section{AN OVERVIEW OF GESTALT THEORY AND ENGLISH TEACHING IN UNIVERSITIES AND \\ COLLEGES}

This part is an overview of gestalt theory and English learning in universities including gestalt theory and gestalt principles, listening comprehension and listening comprehension tests, importance of English vocabulary teaching as well as the necessity of application of gestalt theory in traditional English teaching.

\section{A. Gestalt Theory and Gestalt Principles}

In the field of cognitive linguistics, gestalt theory is described as "categorized basis", and Schmid made a conclusion that there are mainly two steps when a person is judging something. The first step is gestalt perception, then they can discompose objects into attributes. It can be clearly seen that gestalt perception plays an important role in categorization, and some gestalt principles put forward by Pragnanz have a deep and comprehensive understanding of the process of recognition of language. Besides, gestalt theory and principles also have reasonable 
explanations that how vision and hearing organize in people's brain in order to make people produce corresponding language. The guidance of figure grounding theory in the studies of language structures is an important application aspect of gestalt theory. Gestalt principles are mainly divided into four types and they are discussed as follows. [8] The first one is principle of proximity, namely there is a small distance between the individuals so that they can be perceived as a gestalt. The second is similarity principle, which means that two similar individuals can be perceived as a gestalt. The third one is closed principle, namely several outline contoured individuals are generally perceived as one gestalt. The last principle is continuity principle, which means that a continuous individual who cannot be interrupted can be perceived as one gestalt.

\section{B. English Listening Comprehension Tests}

Listening comprehension test is an important means used in English listening teaching, and English listening tests can be generally divided into two types: one is test of identifying sound; the other is comprehension test. This paper mainly put emphasis on English listening comprehension tests, and the test of overall perception ability takes a large proportion in English listening tests. The reason is that the overall perception ability of language contents and forms is an important embodiment of comprehensive language ability. [1] In the view of listening tests professor Buck, listening comprehension is a very complex process so that students should firstly how this process works in order to examine listening comprehension. Therefore, this paper summarizes an important form of listening comprehension on the basis of gestalt principles in order to give some implications to English listening teaching in universities and colleges.

\begin{tabular}{|l|l|l|l|l|}
\hline $\begin{array}{l}\text { Students' } \\
\text { attitude } \\
\text { toward } \\
\text { listening } \\
\text { tests }\end{array}$ & $\begin{array}{l}\text { Very } \\
\text { Like }\end{array}$ & Like & Dislike & $\begin{array}{l}\text { Very } \\
\text { dislike }\end{array}$ \\
\hline & $5 \%$ & $20 \%$ & 50 & $25 \%$ \\
\hline
\end{tabular}

\section{The Importance of English Vocabulary Teaching}

Pronunciation, grammar and vocabulary are three important elements of language, the learning of pronunciation can be finished in only one week, and grammar can also be grasped in several months or years. However, the accumulation of English vocabulary is a lifelong process, and it is also difficult for many learners, but the importance of English vocabulary cannot be ignored. Wilkins once pointed out that many things cannot be expressed without grammar, but nothing can be expressed without vocabulary. Scholars represented by Lewis regarded vocabulary as the center of English teaching. According to studies of cognitive linguistics, language learning begins with vocabulary learning, and it is a process from lexicalization, and syntaticalization to relexicalization. [10] English vocabulary is the most fundamental step and basis of learning English, and students' grasp of English vocabularies can directly have influence on improvement of their comprehensive abilities in listening, speaking, reading, writing and translating. Without proficient grasp of English vocabularies, language abilities and skills of students in universities and colleges cannot be formed and developed. Some studies also proved that there is a close relationship between students' quantities of English vocabularies and English performances in universities and colleges, so that it becomes an important problem urgently to be solved in teaching English in universities and colleges to improve efficiency of English vocabulary teaching.

\section{Necessity of Applying Gestalt Theory in Traditional English Teaching in Universities and Colleges}

Gestalt psychology is also called shaping psychology, and it was proposed and developed by German scholar Koffka in 1912. It is a transliterated name from German, and it means figure or configuration. The main concept of gestalt theory is perceived the whole part, and they attention should be paid to all parts that constitute the whole. The application of gestalt theory in teaching practice is of great significance to improve English classroom teaching effect in universities and colleges. Many English teaches focus their teaching on English vocabulary explanations and analysis of grammatical structures of sentences, so that English teaching in traditional universities and colleges are separated from texts and language contexts. This can help students better grasp grammatical knowledge, but they often ignore the functions of English vocabularies in certain language context. [7] As a result, students will have a poor ability of grasping macro structures of passages, and their English reading ability as well as comprehensive qualities cannot be improved. Therefore, it is necessary to apply gestalt theory into English classroom teaching in universities and colleges so as to optimize classroom language learning contexts and improve English teaching effect.

\section{APPLICATIONS OF GESTALT THEORY IN ENGLISH LISTENING TESTS AND ENGLISH VOCABULARY TEACHING IN UNIVERSITIES}

\section{AND COLLEGES}

The following part discusses the applications and embodiment of gestalt theory and gestalt principles in English listening tests and English vocabulary teaching.

\section{A. Applications of Gestalt Theory and Gestalt Principles in English Listening Tests in Universities and Colleges}

There is a close relationship between English listening comprehension tests and gestalt principles, and different gestalt principles are embodied in different topics.

\section{1) Application of Proximity Principle}

Proximity principle means that two or more individuals of short distance can be perceived as a gestalt, and this kind of proximity is reflected in proximity in actual distance in the process of language understanding, but also it is reflected in the proximity of psychological distance. In other words, people generally summarized 
two or more individuals which can be easily to be associated together as a gestalt. [4] This is very commonly seen in English listening comprehension tests, so that if students hear clearly the key words, they can naturally think of or predict the meaning of who dialogue in order to pick up a right answer. For example,

A: I have so much work to do tonight.

B: Why not ask your husband to help you.

A: Oh, he is a coach potato, you know.

Question: Will the woman's husband help her to

From this example it can be seen this is to examine students" understanding of the idiom "coach potato", so that students should firstly understand the literal meaning of this dialogue on the basis of personalities most similar to "coach potato" in order to choose the right answer. do her work?

\section{2) Application of Similarity Principle}

Similarity principle means that people will perceive two or more individuals of similar characteristics and attributes as one gestalt, and students should form a complete image in their minds by using their overall perception ability, then they can distinguish the attributes of the individuals in order to analyze the intention of the tests.[5] This principle is generally reflected in English listening tests, namely several individuals of same characteristics are put together so that students should find their similarities by this principle. For example,

A: Look, there, elephants. Can I feed them with these

leaves?

B: No, these leaves are for the giraffes. You could give them a banana.

A: But, I want to save the banana for the monkeys there.

Question: Where are the two persons?

\section{A. Zoo B. Farm C. Museum}

This conversation did not tell the place of their conversation clearly, but students can hear "elephant", "giraffe" and "monkey" in their conversation so that students can find similarities between them. They are all animals, and they can be seen in the zoo, thus the answer is obvious.

\section{3) Application of Closed Principle}

Closed principle refers to a closed outline composed by the individuals, and this principle is more applied in the perception of graphs which means that people will naturally regard a closed graph and the object inside the graph as a whole part. This principle is also embodied in language expressions, and they are called semantic closure as well as closure of the logical relationship between sentences. In other words, the understanding of later contents should be based on the understanding of former contents such as causal relationship, adversative relation and parallel relation. For example,

\section{A: I am a freeman from today on. Nobody will tell me what I should do or what I should not anymore.}

B: You do not mean you quitted that well-paid job you have had so long.

Question: Which one describes the woman's reaction

best in the following?

A Overjoyed B Confused C Surprised D Supportive

This is a typical semantic closure in English, and it can be seen that B's response to A is a little surprised and he seems not to believe that, thus negative sentence pattern is used. Therefore, students in universities and colleges can easily understand English listening contents with the help of this principle and find the right answer quickly.

\section{4) Application of Continuity Principle}

Continuity principle means several continuous individuals which cannot be interrupted generally can be perceived as on gestalt. The application of this principle is more direct in the perception of graphs, for example, people will generally consider continuous river and gallery as a whole. However, this principle in English listening is reflected as continuity and sequence of an event. For example,

John get out of the school, turn left, walk along the street, take the second turning on the left and get down the street till the end, then he turn left.

Question: Where does John go?

Topics of indicating the route with graphs are frequently seen in English listening tests, and the most important thing for students in universities and colleges is to find the correct direction by following its order. Therefore, it can also be said a gestalt perception of a process, so that students should firstly perceive the whole map and then perceive specific locations of each places in order to find the right destination and answer quickly.

\begin{tabular}{|l|l|l|l|l|}
\hline $\begin{array}{l}\text { Students' } \\
\text { performance } \\
\text { of Good }\end{array}$ & Listening & Vocabulary & Reading & Writing \\
\hline Before & $20 \%$ & $30 \%$ & $35 \%$ & 40 \\
\hline After & $60 \%$ & $75 \%$ & $50 \%$ & $65 \%$ \\
\hline
\end{tabular}

As a psychological theory, gestalt theory can be applied in language understanding and language expressions to a large extent. Although it can help improve students' English listening comprehension ability with the four gestalt principles, it cannot deal with all kinds of situations, and many principles may be involved in one topic of English listening tests so that English teachers should cultivate a kind of entire perceptual ability of students in learning English in universities and colleges.

\section{B. Application of Gestalt Theory in English Vocabulary \\ Teaching in Universities and Colleges}

In present English vocabulary teaching in many universities and colleges, many teachers directly give students the pronunciation and meanings of English words so that students will be bored of learning English words 
and they cannot use these English words properly in daily life. They do not pay attention to the inner relationship the meaning of words, thus it is difficult for them to enlarge their English vocabulary in universities and colleges. [6] The explanations of an English word are shown from the perspectives of pronunciation, form and meaning, but the emergence of some English words in certain language and social environment is closely related to certain context of use and psychological intention of the users. With the help of gestalt theory, text can provide students semantic background to understand the meanings of English words, and the correctness, vividness as well as figurativeness is reflected in the relationship of textual structures.

\section{CONCLUSION}

In conclusion, this paper mainly makes an analysis of the application of gestalt theory in English listening tests and English vocabulary teaching in universities and colleges. It discusses English listening tests under the guidance of gestalt principles with the aim to find out an effective English listening teaching method in universities and colleges to improve students' English ability. Besides, integrity principle of gestalt theory is applied in English vocabulary teaching based on previous problems in English vocabulary teaching in universities and colleges. In fact, the task of English vocabulary teaching is completed by teachers and students together in universities and colleges. English teachers should make full use of gestalt integrity principle to guide English vocabulary teaching in universities and colleges in order to strengthen vocabulary memorization of students. At the same time, students should also constantly review English words they have learnt in order to retain a fresh memory of English vocabulary.

\section{REFERENCES}

[1] F. Ungerer, H. -J. Schmid, An Introduction to Cognitive Linguistics [M]. Pearson Education Limited,2006

[2] Hu Zhuanglin. Discourse Cohesion and Coherence [M]. Shanghai: Shanghai Foreign Language Education Press, 1994.

[3] Lewis, M. The Lexical Approach: The state of ELT and the way forward [M]. Hove, England: Language Teaching Publications. 1993.

[4] Li Weiqing. English Reading Mode Based on Gestalt Theory [J]. Journal of Yellowston Technology Institute, 2010.

[5] Penny. Ur. A Course in Language Teaching: Practice and Theory [M]. Cambridge University Press.2000.8

[6] Peter Robinson. Cognition and Second Language Instruction [M]. Cambridge University Press.2001

[7] Randal Holme, Cognitive Linguistics and Language Teaching[M]. Palgrave Macmillan, 2009

[8]] Wang Liyan. The Application of Gestalt Psychology in Task-based English Teaching in Universities and Colleges [J]. Industrial \& Science Tribune, 2012

[9] Wilkins DA. Linguistics in Language teaching [M]. London: Edward Arnold. 1978.

[10] Xu Qiang. English Testing Theory and Proposition Practice [M] Hefei: Anhui Education Press, 1992 